Dinamika Kesehatan Jurnal Kebidanan dan Keperawatan Vol 10 No. 1 Juli 2019 ( ISSN: 2086-3454 EISSN: 2549-4058)

url: http://ojs.dinamikakesehatan.unism.ac.id DOI : https://doi.org/10.33859/dksm.v10il.390

Perbedaan Intensitas Nyeri Sebelum dan Sesudah Ambulasi Dini pada Ibu Postpartum Post Seksiosesar

Studi Literatur : Pengaruh Pelatihan Interprofesional Terhadap Self Eficacy

Pada Mahasiswa Kesehatan

\title{
Studi Literatur : Pengaruh Pelatihan Interprofesional Terhadap Self Eficacy Pada Mahasiswa Kesehatan
}

\author{
Nova Ari Pangesti 1, Wiwik Kusumawati2 \\ 1_Mahasiswa Prodi Magister Keperawatan Universitas Muhammadiyah Yogyakarta \\ 2Dosen Fakultas Kedokteran dan Ilmu Keperawatan, Universitas Muhammadiyah \\ Yogyakarta \\ *Email : nopheexcellent@gmail.com Telephone : 087728679855
}

\begin{abstract}
Abstrak
Latar Belakang: Menghadapi tantangan Era Globalisasi maka tenaga kesehatan dituntut dapat menyediakan pelayanan kesehatan yang berkualitas. Pelayanan berkualitas dapat terwujud melalui praktik kolaborasi yang baik antar profesi. Perlu diadakannya praktik kolaborasi sejak dini melalui proses pembelajaran Interprofessional Education. IPE dimulai sejak mahasiwa kesehatan menjalani program profesi. Namun, masalahnya yaitu kurangnya kepercayaan diri mahasiswa saat menjalani profesi. Kenyataannya, mahasiswa farmasi memiliki self eficacy yang rendah daripada mahasiswa kedokteran dan keperawatan sehingga perlu adanya pelatihan interprofesional.

Tujuan: Literatur review ini bertujuan untuk mengkaji tentang pengaruh pelatihan interprofesional terhadap self eficacy pada mahasiswa kesehatan.

Metode: Studi ini diperoleh dari 4 database yaitu E-resources perpustakaan nasional, ERIC, Google Scholar, dan PubMed dengan menggunakan kriteria inklusi dan eksklusi. Kata kunci yang digunakan dalam pencarian literatur ini antara lain: "interprofessional training and self-eficacy", "interprofessional collaborative practice and self confidence".

Hasil: Dari 11 penelitian yang diperoleh, 10 penelitian menyatakan interprofesional secara signifikan meningkatkan self eficacy pada mahasiswa kesehatan.

Kesimpulan: Pelatihan interprofesional dapat membantu mahasiswa dalam mengembangkan keterampilan komunikasi, kerjasama tim dan tim manajemen yang berguna untuk meningkatkan self eficacy sehingga dapat meningkatkan perawatan dan keselamatan pasien.
\end{abstract}

Kata Kunci: Pelatihan Interprofesional, Self eficacy, Mahasiswa Profesi Kesehatan 
Dinamika Kesehatan Jurnal Kebidanan dan Keperawatan Vol 10 No. 1 Juli 2019 ( ISSN: 2086-3454 EISSN: 2549-4058)

url: http://ojs.dinamikakesehatan.unism.ac.id DOI : https://doi.org/10.33859/dksm.v10i1.390

Perbedaan Intensitas Nyeri Sebelum dan Sesudah Ambulasi Dini pada Ibu Postpartum Post Seksiosesar

Studi Literatur : Pengaruh Pelatihan Interprofesional Terhadap Self Eficacy

Pada Mahasiswa Kesehatan

A Literature Review: Effects Of Professional Training On Self Eficacy In Health Students

\begin{abstract}
Background: Facing the challenges of the Globalization Era health workers are required to provide good quality health services. Quality services can be realized through the practice of good collaboration between professions. It is necessary to hold collaborative practices early through the Interprofessional Education learning process. IPE began since health students do a professional program. However, the problem is the lack of confidence in students while undergoing the profession. In fact, pharmaceutical students have a low self-efficacy than medical and nursing students, so need for interprofessional training.

Objective: This literature review aims to analyze the effect of interprofessional training on selfefficacy on health students.

Method: This study was obtained from 4 databases namely the national library E-resources, ERIC, Google Scholar, and PubMed using inclusion and exclusion criteria. The keywords used in this literature search include: "interprofessional training and self-efficacy", "interprofessional collaborative practice and self confidence", etc.

Results: Based on the 11 studies obtained, 10 studies stated that interprofessional training significantly increased self-efficacy in health students.

Conclusion: Interprofessional training can help students develop communication skills, teamwork and management teams that are useful for improving self-efficacy so as to improve patient care and safety.
\end{abstract}

Keywords: Interprofessional Training, Self Efficacy, Health Professional Student

\section{Pendahuluan}

Menghadapi tantangan Era Globalisasi

maka tenaga kesehatan dituntut dapat menyediakan pelayanan kesehatan yang

berkualitas. Pelayanan berkualitas dapat terwujud melalui praktik kolaborasi yang baik antar profesi seperti dokter, perawat, \& apoteker dalam kerjasama tim (Sedyowinarso, dkk., 2011). Dalam pelayanan kesehatan seringkali ditemukan misscommunication antara tenaga kesehatan yang mengakibatkan penurunan kualitas perawatan pasien dan meningkatkan jumlah medical eror. Kurangnya kemampuan komunikasi tersebut karena tidak adanya pelatihan atau pendidikan penerapan kolaborasi antara tenaga kesehatan di masa perkuliahan. Oleh karena itu perlu diadakannya praktik

kolaborasi sejak dini melalui proses pembelajaran menggunakan strategi Interprofessional Education. Pengenalan IPE salah satunya melalui suatu pelatihan yang 
Dinamika Kesehatan Jurnal Kebidanan dan Keperawatan Vol 10 No. 1 Juli 2019 ( ISSN: 2086-3454 EISSN: 2549-4058)

url: http://ojs.dinamikakesehatan.unism.ac.id DOI : https://doi.org/10.33859/dksm.v10i1.390

Perbedaan Intensitas Nyeri Sebelum dan Sesudah Ambulasi Dini pada Ibu Postpartum Post Seksiosesar

Studi Literatur : Pengaruh Pelatihan Interprofesional Terhadap Self Eficacy

Pada Mahasiswa Kesehatan

dilengkapi dengan simulasi dimana merupakan

cara efektif untuk meningkatkan kemampuan

kognitif, afektif dan psikomotor mahasiswa.

IPE biasanya dimulai sejak mahasiwa

kesehatan menjalani program profesi. Namun

masalahnya yaitu kurangnya kepercayaan diri

mahasiswa saat menjalani profesi atau praktek

klinik di Rumah Sakit. Kenyataannya, mahasiswa farmasi memiliki self eficacy yang rendah daripada mahasiswa kedokteran dan keperawatan (Hagemeier et al., 2014). Mahasiswa farmasi dituntut untuk mampu bertindak profesional meskipun mereka memiliki self eficacy, kompetensi dan kemampuan klinik yang kurang baik (Wen, 1994). Untuk meningkatkan self eficacy pada mahasiswa perlu adanya pelatihan interprofesional. Melalui pelatihan peserta dapat mengeksplorasi cara kolaboratif untuk meningkatkan aspek komunikatif perawatan klinis. Pelatihan interprofesional memperkuat kompetensi mahasiswa dalam kolaborasi antar profesi (Ponzer et al., 2004). Penelitian Liaw, S.Y. et. al (2011) menjelaskan bahwa pelatihan interprofesional di tingkat sarjana telah memberikan kesempatan mahasiswa kedokteran dan keperawatan sebagai pengembangan awal keterampilan komunikasi dan kerjasama interprofesi.

Pelatihan interprofesional akan meningkatkan self efficacy mahasiswa lebih dari sekedar pelatihan klinis tradisional dan memiliki pengaruh yang positif terhadap self efficacy pada mahasiswa kedokteran \& keperawatan (Nørgaard et al., 2013; Hagemeier et al., 2014). Penelitian serupa juga menyatakan bahwa terdapat dampak pelatihan interprofesional terhadap pembelajaran yang dirasakan mahasiswa dan perubahan sikap dalam rangkaian eksperimental (Cooper et al 2005, Lindqvist et al., 2005). Sedangkan penelitian yang dilakukan Wlliams et al., (2017) menunjukkan tidak ada efek interaksi antara umur dan jenis kelamin pada skor selfefficacy dan tidak ada peningkatan yang signifikan self-efficacy dalam interprofessional training. Berdasarkan beberapa penelitian di atas maka peneliti tertarik melakukan studi literatur untuk mengkaji tentang pengaruh pelatihan 
Dinamika Kesehatan Jurnal Kebidanan dan Keperawatan Vol 10 No. 1 Juli 2019 ( ISSN: 2086-3454 EISSN: 2549-4058)

url: http://ojs.dinamikakesehatan.unism.ac.id DOI : https://doi.org/10.33859/dksm.v10i1.390

Perbedaan Intensitas Nyeri Sebelum dan Sesudah Ambulasi Dini pada Ibu Postpartum Post Seksiosesar

Studi Literatur : Pengaruh Pelatihan Interprofesional Terhadap Self Eficacy

Pada Mahasiswa Kesehatan

interprofesional terhadap self eficacy pada

mahasiswa kesehatan.

\section{Metode}

Penelitian ini merupakan sebuah studi

literatur yang merangkum beberapa literatur yang relevan dengan tema. Pencarian literatur menggunakan 2 database yaitu E-resources perpustakaan nasional melalui ProQuest, dan Taylor \& Francis serta database ERIC

\section{(Education Resources Information Center)}

didapatkan melalui Ebsco. Kemudian sebagai tambahan peneliti juga melakukan pencarian melalui Google Scholar, dan PubMed. Kata kunci yang digunakan dalam pencarian literatur antara lain: “interprofessional training and self-eficacy”, "interprofessional education + self eficacy", "self eficacy", “interprofessional collaborative practice and self eficacy”, "interprofessional collaborative practiceand self confidence”, "interprofessional training and self confidence", dan "interprofessional education + confidence”.

Literatur yang digunakan adalah literatur yang dipulikasikan dari tahun 2000 s.d tahun 2017. Seluruh literatur kemudian diseleksi kembali dengan menggunakan kriteria inklusi dan eksklusi. Flow diagram dari pencarian dan proses seleksi literatur digambarkan pada Gambar 1.



Gambar 1. Diagram Alur Proses Seleksi Literatur 
Dinamika Kesehatan Jurnal Kebidanan dan Keperawatan Vol 10 No. 1 Juli 2019 ( ISSN: 2086-3454 EISSN: 2549-4058)

url: http://ojs.dinamikakesehatan.unism.ac.id DOI : https://doi.org/10.33859/dksm.v10i1.390

Perbedaan Intensitas Nyeri Sebelum dan Sesudah Ambulasi Dini pada Ibu Postpartum Post Seksiosesar

Studi Literatur : Pengaruh Pelatihan Interprofesional Terhadap Self Eficacy

Pada Mahasiswa Kesehatan

\section{Hasil}

Berdasarkan hasil review dari 11 literatur yang memenuhi kriteria inklusi maka didapatkan hasil

sebagai berikut:

Tabel 1. Ringkasan dari literatur tentang pengaruh interprofessional training terhadap self efficacy

\begin{tabular}{|c|c|c|c|c|c|c|c|}
\hline $\begin{array}{l}\mathrm{N} \\
\mathrm{o}\end{array}$ & $\begin{array}{l}\text { Author } \\
\text { /Jurnal }\end{array}$ & $\begin{array}{l}\text { Jenis Pelatihan } \\
\text { interprofesional }\end{array}$ & Durasi Training & $\begin{array}{c}\text { Instrumen atau } \\
\text { metode } \\
\text { pengumpulan data }\end{array}$ & Self eficacy & Signifikasi & Resume \\
\hline 1 & $\begin{array}{l}\text { (Hagemeier et } \\
\text { al., 2014) }\end{array}$ & $\begin{array}{l}\text { Interprofessional } \\
\text { communication } \\
\text { course }\end{array}$ & $\begin{array}{l}3 \text { jam setiap } \\
\text { minggu }\end{array}$ & $\begin{array}{l}\text { Kuesioner berisi } \\
\text { 33-item } \\
\text { pertanyaan } \\
\text { tentang tujuan } \\
\text { dan kompetensi } \\
\text { IPEC }\end{array}$ & $\begin{array}{l}\text { - Mahasiswa } \\
\text { kedokteran : + } \\
\text { (Mean: 89,06) } \\
\text { - Mahasiswa } \\
\text { keperawatan : } \\
\text { + (Mean : } \\
\text { 95,83) } \\
\text { - Mahasiswa } \\
\text { farmasi:+ } \\
\text { (Mean: } 91,56) \\
\end{array}$ & $\mathrm{P}<0,001$ & $\begin{array}{l}\text { Pelatihan keterampilan } \\
\text { komunikasi } \\
\text { interprofesional } \\
\text { berpengaruh positif } \\
\text { terhadap self-efficacy } \\
\text { beliefs pada mahasiswa } \\
\text { kedokteran, keperawatan } \\
\text { dan farmasi. }\end{array}$ \\
\hline 2 & $\begin{array}{l}\text { (Watters, et } \\
\text { al.,2017) }\end{array}$ & $\begin{array}{l}\text { Interprofessional } \\
\text { simulation }\end{array}$ & $\begin{array}{l}\text { Masing - } \\
\text { masing kursus } 1 \\
\text { hari dan } 15 \\
\text { menit per } \\
\text { skenario }\end{array}$ & $\begin{array}{l}\text { Kuesioner berisi } \\
10 \text { item } \\
\text { pertanyaan } \\
\text { tentang } \\
\text { kepemimpinan, } \\
\text { manajemen } \\
\text { situasi, } \\
\text { kerjasama tim, } \\
\text { dan kemampuan } \\
\text { komunikasi }\end{array}$ & $\begin{array}{l}\text { - Mahasiswa } \\
\text { keperawatan : } \\
+ \\
\text { - Mahasiswa } \\
\text { kedokteran : + }\end{array}$ & $\begin{array}{l}p<0.001 \\
\text { IP Vs UP } \\
20 \%: 12 \%\end{array}$ & $\begin{array}{l}\text { Pelatihan } \\
\text { interprofesional } \\
\text { menunjukkan } \\
\text { peningkatan efek positif } \\
\text { pada self-efficacy untuk } \\
\text { mahasiswa perawat dan } \\
\text { dokter. }\end{array}$ \\
\hline 3 & $\begin{array}{l}\text { (Nørgaard et } \\
\text { al., 2013) }\end{array}$ & $\begin{array}{l}\text { Interprofessional } \\
\text { clinical study (ICS) }\end{array}$ & 2 minggu & $\begin{array}{l}\text { - Online } \\
\text { kuesioner yang } \\
\text { menyangkut } \\
\text { self-efficacy } \\
\text { dalam } \\
\text { kolaborasi } \\
\text { interprofesional }\end{array}$ & $\begin{array}{l}\text { - } \text { Intervensi } \\
\text { Group setelah } \\
\text { ICS : + } \\
\text { - } \text { Kontrol Group } \\
\text { setelah } \\
\text { pelatihan } \\
\text { klinik } \\
\text { tradisional : - }\end{array}$ & $\mathrm{p}=0.08$ & $\begin{array}{l}\text { Pelatihan } \\
\text { interprofesional } \\
\text { meningkatkan persepsi } \\
\text { mahasiswa akan self- } \\
\text { efficacy lebih dari } \\
\text { pelatihan klinis } \\
\text { tradisional }\end{array}$ \\
\hline $\begin{array}{l}4 \\
.\end{array}$ & $\begin{array}{l}\text { (Williams et } \\
\text { al., 2017) }\end{array}$ & $\begin{array}{l}\text { Interprofessional } \\
\text { education and } \\
\text { practice }\end{array}$ & $2 \mathrm{x}$ seminggu & $\begin{array}{l}\text { The Self- } \\
\text { Efficacy for } \\
\text { Inter } \\
\text { professional } \\
\text { Experiential } \\
\text { Learning } \\
\text { (SEIEL) Scale }\end{array}$ & $\begin{array}{l}\text { paramedic } \\
\text { practice : } \\
\text { public health, and } \\
\text { social work. } \\
\text { (mean : 57,4) } \\
\text { - Male : ++ } \\
\text { - Female : + }\end{array}$ & $\begin{array}{l}P=0,249 \\
P=0,555\end{array}$ & $\begin{array}{l}\text { Tidak ada hubungan } \\
\text { skore self efikasi yang } \\
\text { signifikan pada ketiga } \\
\text { disiplin ilmu }\end{array}$ \\
\hline 5 & $\begin{array}{l}\text { (Brock et al., } \\
\text { 2013) }\end{array}$ & $\begin{array}{l}\text { Interprofessional } \\
\text { TeamSTEPPS- } \\
\text { based training }\end{array}$ & Periode 4 hari & $\begin{array}{l}\text { - TeamSTEPPS } \\
\text { Teamwork } \\
\text { Attitudes } \\
\text { Questionnaire } \\
\text { (TAQ) } \\
\text { - Kuesioner } \\
\text { tentang Sikap, } \\
\text { Motivasi dan } \\
\text { Self-Efficacy } \\
\text { (AMUSE) } \\
\end{array}$ & $\begin{array}{ll}\text { - } & \text { Mahasiswa } \\
& \text { kedokteran:++ } \\
\text { (mean: 3,29) } \\
\text { - } & \text { Mahasiswa } \\
& \text { keperawatan : } \\
& + \\
& \text { (mean : 3,67) } \\
- & \text { Mahasiswa } \\
& \text { Farmasi:+ } \\
& \text { Mean }(3,56) \\
\end{array}$ & $\mathrm{p}<0,001$ &  \\
\hline 6 & $\begin{array}{l}\text { (Boland et al., } \\
\text { 2016) }\end{array}$ & $\begin{array}{l}\text { Interprofessional } \\
\text { immersion training }\end{array}$ & 32 jam training & $\begin{array}{ll}\text { - } & \text { Team Skills } \\
\text { Scale (TSS) dan } \\
\text { (ATHCT), } \\
\text { - Interprofessiona } \\
\text { 1 Collaborative } \\
\text { Competencies } \\
\text { Questionnaire } \\
\text { (IPECQ) }\end{array}$ & $\begin{array}{l}\text { TSS skor pre- } \\
\text { test }(\mathrm{M}=3.50, \\
\text { lebih renda } \\
\text { dari post-test } \\
\text { (M = 4.32, } \\
\text { - IPECQ skor } \\
\text { pre-test scores } \\
\text { lebih rendah } \\
(\mathrm{M}=2.77, \\
\text { daripada post- }\end{array}$ & $\mathrm{p}=0.001$ & $\begin{array}{l}\text { Setelah menyelesaikan } \\
\text { pelatihan trainer merasa } \\
\text { lebih percaya diri dalam } \\
\text { kemampuan mereka } \\
\text { untuk bekerja dengan } \\
\text { interprofesional tim. }\end{array}$ \\
\hline
\end{tabular}


Dinamika Kesehatan Jurnal Kebidanan dan Keperawatan Vol 10 No. 1 Juli 2019 ( ISSN: 2086-3454 EISSN: 2549-4058)

url: http://ojs.dinamikakesehatan.unism.ac.id DOI : https://doi.org/10.33859/dksm.v10i1.390

Perbedaan Intensitas Nyeri Sebelum dan Sesudah Ambulasi Dini pada Ibu Postpartum Post Seksiosesar

Studi Literatur : Pengaruh Pelatihan Interprofesional Terhadap Self Eficacy

Pada Mahasiswa Kesehatan

\begin{tabular}{|c|c|c|c|c|c|c|c|}
\hline & & & & & $\begin{array}{l}\text { test skor }(\mathrm{M}= \\
3.45)\end{array}$ & & \\
\hline 7 & $\begin{array}{l}\text { (Tofil et al., } \\
\text { 2014) }\end{array}$ & $\begin{array}{l}\text { Interprofessional } \\
\text { Simulation Training }\end{array}$ & $\begin{array}{l}4 \text { minggu } \\
\text { sekali, } 1 \text { jam } \\
\text { sesi simulasi }\end{array}$ & $\begin{array}{l}\text { Kuesioner berisi } \\
6 \text { item evaluasi } \\
\text { menggunakan } \\
\text { anchored }\end{array}$ & 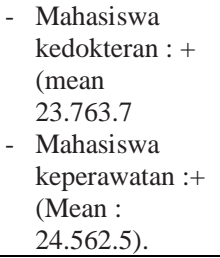 & $\mathrm{P}<0.0001$ & $\begin{array}{l}\text { Pelatihan simulasi } \\
\text { interprofesional untuk } \\
\text { keperawatan dan } \\
\text { kedokteran berpotensi } \\
\text { meningkatkan self } \\
\text { eficacy dalam } \\
\text { komunikasi serta sikap } \\
\text { tim yang lebih baik }\end{array}$ \\
\hline 8 & $\begin{array}{l}\text { (Hylin et al., } \\
2007 \text { ) }\end{array}$ & $\begin{array}{l}\text { Interprofessional } \\
\text { course }\end{array}$ & 2 minggu & $\begin{array}{l}\text { - Online } \\
\text { kuesioner }\end{array}$ & $\begin{array}{ll}\text { - } & \text { Nurses :+ } \\
\text { - } & \text { Physiotherapist } \\
& \mathrm{s}:+ \\
\text { - } & \text { Physicians : < } \\
\text { - } & \text { Occupational } \\
& \text { therapists : + }\end{array}$ & $\mathrm{P}=0.05$ & $\begin{array}{l}\text { Kursus dinilai sangat } \\
\text { bagus dan sebagian besar } \\
\text { mahasiswa memiliki } \\
\text { kesan positif }\end{array}$ \\
\hline 9 & $\begin{array}{l}\text { (Oza et al., } \\
2015)\end{array}$ & $\begin{array}{l}\text { Interprofessional } \\
\text { collaborative } \\
\text { practice (IPCP) }\end{array}$ & $\begin{array}{l}20 \text { jam per } \\
\text { kasus, Setiap } \\
\text { pertemuan } \\
\text { berlangsung } 15 \\
\text { menit }\end{array}$ & $\begin{array}{l}\text { Kuesioner berisi } \\
\text { 11-item } \\
\text { checklist } \\
\text { berdasarkan } \\
\text { tujuan dan } \\
\text { kompetensi } \\
\text { IPCP SEIEL }\end{array}$ & $\begin{array}{l}\text { - } \text { interprofession } \\
\text { al teamwork: } \\
+ \\
\text { - patientcentered } \\
\text { communicatio } \\
\text { n. }+\end{array}$ & $\mathrm{P}=0.01$ & $\begin{array}{l}\text { Penampilan mahasiswa } \\
\text { kesehatan dalam IPCP } \\
\text { berhubungan dengan self } \\
\text { eficacy interprofessional } \\
\text { teamwork and patient } \\
\text { centered } \\
\text { communication. }\end{array}$ \\
\hline $\begin{array}{l}1 \\
0\end{array}$ & $\begin{array}{l}\text { (Schaik, et al. } \\
\text { 2011) }\end{array}$ & $\begin{array}{l}\text { interprofessional } \\
\text { team training }\end{array}$ & $\begin{array}{l}18 \text { sesi per } \\
\text { tahun dalam } 2 \\
\text { unit. Setiap sesi, } \\
2 \text { skenario } \\
\text { sekitar } 10 \text { menit } \\
\text { setiap skenario } \\
\text { dan } \\
20 \text { menit untuk } \\
\text { pembekalan. }\end{array}$ & $\begin{array}{l}\text { - } 20 \text { item yang } \\
\text { berhubungan } \\
\text { dengan self } \\
\text { assessed tingkat } \\
\text { kepercayaan } \\
\text { diri }\end{array}$ & $\begin{array}{l}\text { - Resident : } \\
\text { mock codes ( } \\
+ \text { ) } \\
\text { real codes : - } \\
\text { - Mahasiswa } \\
\text { keperawatan : } \\
\text { Mock codes } \\
(+) \\
\text { real codes : + }\end{array}$ & $P=.009$ & $\begin{array}{l}\text { Pelatihan simulasi } \\
\text { interprofesional tim telah } \\
\text { memiliki efek yang } \\
\text { menguntungkan pada } \\
\text { self eficacy dalam } \\
\text { keterampilan resusitasi } \\
\text { pada resident dan } \\
\text { mahasiswa keperawatan }\end{array}$ \\
\hline $\begin{array}{l}1 \\
1 \\
.\end{array}$ & $\begin{array}{l}\text { (Holthaus, et } \\
\text { al. 2015) }\end{array}$ & $\begin{array}{l}\text { Interprofessional } \\
\text { simulation }\end{array}$ & $\begin{array}{l}\text { selama periode } \\
10 \text { bulan dengan } \\
\text { pertemuan } \\
\text { mingguan } 10 \\
\text { menit }\end{array}$ & 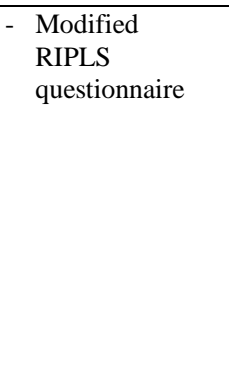 & $\begin{array}{l}\text { - Mahasiswa } \\
\text { keperawatan: + } \\
\text { (Mean : 8.70) } \\
\text { - Medical } \\
\text { dietetics :+ } \\
\text { (Mean : 9.91) } \\
\text { - Mahasiswa } \\
\text { Kedokteran: + } \\
\text { (Mean :8.75) } \\
\text { - Mahasiswa } \\
\text { Farmasi : } \\
\text { (Mean : 9.09) }\end{array}$ & $\mathrm{P} \leq 0,05$ & $\begin{array}{l}\text { Simulasi IPE } \\
\text { meningkatkan } \\
\text { pemahaman tentang } \\
\text { profesi dan self-efficacy }\end{array}$ \\
\hline
\end{tabular}

\section{Pembahasan}

\section{Interprofessional training}

Jenis Interprofessional training yang

digunakan dari 11 artikel yang telah direview

antara lain: sebuah studi menggunakan jenis
(Hagemeier et al., 2014), tiga studi menggunakan pelatihan interprofesional simulasi (Watters et al., 2017; Holthaus, 2013; Tofil et al., 2014), dua buah studi menggunakan jenis interprofessional education and practice dan interprofessional 
Dinamika Kesehatan Jurnal Kebidanan dan Keperawatan Vol 10 No. 1 Juli 2019 ( ISSN: 2086-3454 EISSN: 2549-4058)

url: http://ojs.dinamikakesehatan.unism.ac.id DOI : https://doi.org/10.33859/dksm.v10i1.390

Perbedaan Intensitas Nyeri Sebelum dan Sesudah Ambulasi Dini pada Ibu Postpartum Post Seksiosesar

Studi Literatur : Pengaruh Pelatihan Interprofesional Terhadap Self Eficacy

Pada Mahasiswa Kesehatan

collaborative practice (IPCP) (Williams,

Brett., 2017; Oza et al., 2015), sebuah studi

dengan tipe interprofessional clinical study

(ICS) (Nørgaard et al., 2013), sebuah studi menggunakan interprofessional Team

STEPPS-based training (Brock et al., 2013),

sebuah studi menggunakan jenis

Interprofessional immersion training (Boland

et al., 2016), sebuah studi dengan tipe

interprofessional course (Hylin et al., 2007),

dan 1 penelitian menggunakan

Interprofessional team training (Schaik, et al.

2011).

\section{Instrument}

Terdapat beberapa instrumen yang telah digunakan untuk mengukur self eficacy pada mahasiswa kesehatan dalam literatur yang telah direview, 2 penelitian menggunakan online kuesioner atau kuesioner berbasis web (Nørgaard et al., 2013 \& Hylin et al., 2007), satu penelitian mengukur tingkat self eficacy menggunakan Skala Pembelajaran Interprofessional Experiential Learning (SEIEL) (Williams et al., 2017), sebuah penelitian mengunakan Modified RIPLS questionnaire (Holthaus et al., 2013), sebuah penelitian mengunakan kuesioner yang berisi 20 item pertanyaan tentang self assessed confidence levels (Schaik, et al. 2011), sebuah penelitian menggunakan 2 instrument penelitian yaitu Team Skills Scale (TSS) untuk mengukur self-report dan sikap perilaku kesehatan Teams-14 item version (ATHCT14), dan tiga penelitian mengunakanan Interprofessional Collaborative Competencies Questionnaire (IPECQ) (Boland et al., 2016; Hagemeier et al., 2014 ; Oza et al., 2015), sebuah penelitian mengunakan Teamwork Attitudes Questionnaire (TAQ) and Attitudes, Motivation, Utility and Self-Efficacy (AMUSE) (Brock et al., 2013) serta satu studi menggunakan anchored kuesioner (Tofil et al., 2014).

\section{Hasil dari Interprofessional Training}

Berdasarkan 11 literatur yang telah direview didapatkan hasil bahwa sepuluh studi menyatakan ada peningkatan self eficacy yang diperoleh dari hasil mengikuti interprofessional training atau interprofesional simulasi dan sejenisnya 
Dinamika Kesehatan Jurnal Kebidanan dan Keperawatan Vol 10 No. 1 Juli 2019 ( ISSN: 2086-3454 EISSN: 2549-4058)

url: http://ojs.dinamikakesehatan.unism.ac.id DOI : https://doi.org/10.33859/dksm.v10i1.390

Perbedaan Intensitas Nyeri Sebelum dan Sesudah Ambulasi Dini pada Ibu Postpartum Post Seksiosesar

Studi Literatur : Pengaruh Pelatihan Interprofesional Terhadap Self Eficacy

Pada Mahasiswa Kesehatan

(Hagemeier et al., 2014; Watters et al., 2017;

Holthaus et al., 2013; Brock et al., 2013;

Boland et al., 2016; Hylin et al., 2007; Oza et

al., 2015; Schaik, et al. 2011). Hanya satu studi menunjukkan tidak ada peningkatan yang signifikan self-efficacy dalam interprofessional training (Williams et al., 2017). Ada 4 domain yang diteliti yaitu kepemimpinan, komunikasi, kerjasama, dan manajemen situasi.

4. Pengaruh interprofesional training terhadap self eficacy

Dari 11 penelitian yang telah direview tentang dampak interprofesional training terhadap self eficacy, 10 penelitian menyatakan adanya pengaruh. Namun masih ada satu penelitian yang menunjukkan bahwa interprofessional training tersebut tidak memiliki dampak signifikan pada self eficacy (Williams et al., 2017). Penelitian tersebut menyebutkan tidak ada hubungan antara jenis kelamin dan umur terhadap skor self-efficacy dengan $\mathrm{p}=0,555$. Demikian pula, sebuah studi Amerika pada mahasiswa psikologi yang menunjukkan tidak ada perbedaan self-efficacy dalam belajar (Kitsantas \& Zimmerman, 2009).

Berdasarkan beberapa penelitian dapat disimpulkan bahwa sebagian besar menunjukkan ada pengaruh yang signifikan dari interprofessional training terhadap self eficacy yang disebabkan karena setelah mengikuti pelatihan mahasiswa menjadi lebih percaya diri terhadap kemampuan mereka baik dari segi kemampuan komunikasi, kepemimpinan, manajemen situasi maupun kerjasama dengan sesama profesi kesehatan. Hal ini terbukti dari hasil review yang menujukkan bahwa terdapat 9 penelitian yang menyatakan bahwa setelah mengikuti interprofesional training mahasiswa atau subjek memiliki self efficacy yang baik dalam kemampauan kerjasama dengan profesi kesehatan lain, 7 penelitian yang menyatakan bahwa responden lebih memiliki self efficacy dalam kemampuan komunikasi setelah mendapatkan pelatihan inter profesional atau simulasi, dan 4 penelitian menyatakan bahwa mahasiswa lebih percaya diri setelah melakukan inter professional training dalam 
Dinamika Kesehatan Jurnal Kebidanan dan Keperawatan Vol 10 No. 1 Juli 2019 ( ISSN: 2086-3454 EISSN: 2549-4058)

url: http://ojs.dinamikakesehatan.unism.ac.id DOI : https://doi.org/10.33859/dksm.v10i1.390

Perbedaan Intensitas Nyeri Sebelum dan Sesudah Ambulasi Dini pada Ibu Postpartum Post Seksiosesar

Studi Literatur : Pengaruh Pelatihan Interprofesional Terhadap Self Eficacy

Pada Mahasiswa Kesehatan

kemmampuan mereka memanajemen situasi

dan 3 penelitian menunjukkan peningkatan self

efficacy tentang kemampuan dalam leadership.

Hal tersebut sejalan dengan penelitian

(Boland et al., 2016; Tofil et al., 2014;

Holthaus, et al. 2015) yang menyatakatan

setelah menyelesaikan pelatihan atau simulasi

IPE dapat meningkatkan pemahaman tentang

profesi dan self-efficacy serta merasa lebih

percaya diri dalam kemampuan mereka untuk

komunikasi, dan bekerja dengan rekan kerja

dalam interprofesional tim. Sebuah

keterampilan yang mereka bawa ketika mereka

akan memasuki dunia kerja (Hagemeier et al.,

2014 \& Watters et al., 2017).

Terdapat 5 penelitian menjelaskan tidak ada perbedaan tingkat self eficacy dianatara profesi kesehatan karena dimana pada disiplin ilmu seperti profesi keperawatan, farmasi, kedokteran tersebut sama-sama mengalami peningkatan self eficacy setelah dilakukan interprofessional training atau sejenisnya dll. (Hagemeier et al., 2014; Watters, et al., 2017 ; Tofil et al., 2014; Holthaus, et al. 2015). Pelatihan interprofesional meningkatkan seluruh tingkat kepercayaan diri atau lebih spesifik kepada tingkat self eficacy dengan nilai $\mathrm{p}<0,001$ (Watters et al., 2017). Selain itu juga didapatkan hasil pelatihan interprofesional tim mendorong peserta untuk mengembangkan kompetensi inti untuk melakukan praktek kolaboratif interprofesional yang distandarkan oleh Pakar IPEC Panel (2011). Sebuah penelitian yang dilakukan (Boland et al., 2016; Schaik, et al. 2011) menemukan bahwa self efficacy mahasiswa untuk kerja tim interprofesional secara signifikan terkait dengan IPCP. Keterlibatan dalam profesionalisme kegiatan ekstrakurikuler dapat meningkatkan keefektifan diri mahasiswa melalui pengaruh yang kuat, kesempatan untuk berlatih keterampilan IPCP dalam konteks stres yang lebih rendah daripada lingkungan evalutive universitas kedokteran.

$$
\text { Sejalan dengan (WHO, 2010) }
$$

menjelaskan efektivitas training dalam interprofessional education dapat berkontribusi untuk menyiapkan praktek kolaborasi di dunia kerja dan beberapa review 
Dinamika Kesehatan Jurnal Kebidanan dan Keperawatan Vol 10 No. 1 Juli 2019 ( ISSN: 2086-3454 EISSN: 2549-4058)

url: http://ojs.dinamikakesehatan.unism.ac.id DOI : https://doi.org/10.33859/dksm.v10i1.390

Perbedaan Intensitas Nyeri Sebelum dan Sesudah Ambulasi Dini pada Ibu Postpartum Post Seksiosesar

Studi Literatur : Pengaruh Pelatihan Interprofesional Terhadap Self Eficacy

Pada Mahasiswa Kesehatan

penelitian menunjukan bahwa kolaborasi ini

dapat meningkatkan perawatan pasien dan

keselamatan pasien. Pelatihan tim

interprofesional meningkatkan kesejahteraan

para mahasiswa kesehatan yang dirasakan

dalam kolaborasi antar profesi dibandingkan

dengan pendidikan klinis tradisional

(Nørgaard et al., 2013). Self-efficacy dipilih

sebagai variabel hasil seperti yang dimilikinya

sebelumnya telah terbukti menjadi metode

yang efisien dan andal untuk memantau

manfaat profesional dalam menghadiri

pelatihan keterampilan komunikasi

(Ammentorp et al 2007; Ammentorp \&

Kofoed 2009; Nørgaard 2011)

Berbagai instrumen telah digunakan

untuk mengukur self eficacy. Dengan

demikian, hasil yang tidak signifikan dapat

dikaitkan dengan penggunaan instrumen

pengukuran yang berbeda. Sebagian besar

penelitian menggunakan SEIEL dan

Interprofessional Collaborative Competencies

Questionnaire (IPECQ). Pertanyaan yang

muncul adalah apakah skala pengukuran

dalam self eficacy tepat untuk mengukur efikasi diri dalam pelatihan interprofesional.

Sedangkan self eficacy tergantung pada

gender, pengalaman terdahulu, kognitif,

motivasi, afektif dan seleksi. Menurut

Bandura, ada empat faktor yang berkontribusi

terhadap pengembangan self efficacy:

Prestasi yang berkaitan dengan pengalaman penguasaan keterampilan yang relevan sebelumnya cenderung meningkatkan selfefficacy sementara kegagalan cenderung menguranginya dan faktor paling kuat dalam pengembangan self-efficacy yang dirasakan;

(b) pengalaman, menyaksikan prestasi orang lain dapat meningkatkan kepercayaan diri mereka sendiri terhadap kemampuan mereka untuk usaha yang sama atau serupa; (c) persuasi verbal dari orang lain dapat meningkatkan self-efficacy, jika itu realistis; dan (d) keadaan fisiologis, perasaan seperti ketegangan atau kecemasan dapat mempengaruhi kinerja (Bandura, 1982; Van Dinther et al., 2011).

Kelemahan dari beberapa penelitian ini meskipun skor self efficacy meningkat secara signifikan setelah pelatihan interprofesional, 
Dinamika Kesehatan Jurnal Kebidanan dan Keperawatan Vol 10 No. 1 Juli 2019 ( ISSN: 2086-3454 EISSN: 2549-4058)

url: http://ojs.dinamikakesehatan.unism.ac.id DOI : https://doi.org/10.33859/dksm.v10i1.390

Perbedaan Intensitas Nyeri Sebelum dan Sesudah Ambulasi Dini pada Ibu Postpartum Post Seksiosesar

Studi Literatur : Pengaruh Pelatihan Interprofesional Terhadap Self Eficacy

Pada Mahasiswa Kesehatan

tidak diketahui apakah perbaikan pada self

efficacy yang dirasakan menyebabkan perilaku

tim yang lebih kolaboratif. Dengan demikian,

penelitian lebih lanjut dengan rancangan yang

lebih ketat diperlukan untuk mengklarifikasi

efek pelatihan interprofesional terhadap self

eficacy. Self efficacy juga bisa dimodifikasi

dengan intervensi kurikuler. Misalnya, sebuah

studi baru-baru ini tentang sebuah program

remediasi Bagi mahasiswa kedokteran yang

berbasis pada mempromosikan self efficacy

menemukan perbaikan signifikan dalam self

efficacy mahasiswa kedokteran dan kinerja

OSCE (Malau-Aduli et al 2013). Studi lebih

lanjut diperlukan untuk memahami kontribusi

kurikulum formal di Universitas kepada self

efficacy mahasiswa untuk dan keterlibatan

dengan IPCP.

\section{Simpulan}

Literatur review ini menunjukkan

bahwa interpofessional training memiliki

pengaruh terhadap self eficacy pada

mahasiswa kesehatan. Pelatihan

interprofesional dapat membantu mahasiswa

dalam mengembangkan keterampilan terutama kemampuan dalam kerjasama tim,

kemampuan komunikasi, manajemen situasi

dan kepemimpinan yang berguna untuk

meningkatkan self eficacy mengahadapi

kolaborasi antar profesi di dunia kerja.

Peningkatan self eficacy diharapkan dapat

memberikan dampak positif bagi mahasiswa

keperawatan, kedokteran, dan farmasi.

Implementasi dari pelatihan interprofesional

meningkatkan perawatan serta keselamatan

pasien. Diharapkan institusi dapat

mengembangkan kurikulum interprofessional

training sejak dini awal pada semester perkuliahan.

\section{Daftar Pustaka}

Bandura, A. (1982). Self efficacy mechanism in human agency. American Psychologist, 37, 122-147.

Boland, D.H., Scott, M.A., Kim, H., White, T., Adams, E., (2016). Interprofessional immersion: Use of interprofessional education collaborative competencies in side-by-side training of family medicine, pharmacy, nursing, and counselling psychology trainees. J. Interprof. Care 30, 739-746. https://doi.org/10.1080/13561820.20 16.1227963

Brock, D., Abu-Rish, E., Chiu, C.-R., Hammer, D., Wilson, S., Vorvick, L., Blondon, K., Schaad, D., Liner, D., Zierler, B., (2013). Republished: 
Interprofessional education in team communication: working together to improve patient safety. Postgrad. Med. J. 89, 642-651. https://doi.org/10.1136/postgradmedj -2012-000952rep

Hagemeier, N. E. (2017). Impact of an Interprofessional Communication Course on Nursing, Medical and Pharmacy Students" Communication Skill Self Efficacy Beliefs,. American Journal of Pharmaceutical Education. , 78 (10) Article 186. .

Holthaus, V. (2015). The Impact of Interprofessional. Wolters Kluwer Health, Vol. 30, No. 2, pp. 127-142. DOI: 10.1097/TIN.0000000000000027.

Hylin, U., Nyholm, H., Mattiasson, A.-C., Ponzer, S., (2007). Interprofessional training in clinical practice on a training ward for healthcare students: A two-year follow-up. J. Interprof. Care 21, 277-288. https://doi.org/10.1080/13561820601 095800

Johannsson, S.L., Wertenberger, D.H., (1996). Using simulation totest critical thinking skills of nursing students. Nurse Educ. Today 16, 323-327.

Nørgaard, B., Draborg, E., Vestergaard, E., Odgaard, E., Jensen, D.C., Sørensen, J., (2013). Interprofessional clinical training improves self-efficacy of health care students. Med. Teach. 35, e1235-e1242.

https://doi.org/10.3109/0142159X.20 12.746452
Oza, S.K., Boscardin, C.K., Wamsley, M., Sznewajs, A., May, W., Nevins, A., Srinivasan, M., E. Hauer, K., (2015). Assessing 3rd year medical students' interprofessional collaborative practice behaviors during a standardized patient encounter: A multi-institutional, cross-sectional study. Med. Teach. 37, 915-925. https://doi.org/10.3109/0142159X.20 14.970628

Schaik, S. M. (2011). Interprofessional Team Training. SAGE , 50(9) 807-815. DOI: $10.1177 / 0009922811405518$.

Sedyowinarso, M., Fauziah, F. A., Aryakhiyati, N., Julica, M. P., Munira, L.,Sulistyowati, E., dkk. (2011). Persepsi Mahasiswa dan Dosen Pendidik terhadap Model Pembelajaran Interprofessional Education (IPE). Kajian Nasional Mahasiswa Ilmu Kesehatan Indonesia.

Tofil, N. M. (2014). Interprofessional Simulation Training Improves Knowledge. Journal of Hospital Medicine Vol 9 | No 3 , DOI 10.1002/jhm.2126.

Watters, C. (2017). Does interprofessional simulation increase self efficacy : a Comparative Study.. BMJ Open , doi:10.1136/bmjopen-2014-005472.

Williams, B., Beovich, B., Ross, L., Wright, C., Ilic, D., (2017). Self-efficacy perceptions of interprofessional education and practice in undergraduate healthcare students. J. Interprof. Care 31, 335-341. https://doi.org/10.1080/13561820.20 17.1286637 